\title{
The Trend of Naturalism in Libertine Poetry of the Later English Renaissance
}

\author{
Saad El-Gabalawy
}

The concept of 'naturalism' and 'primitivism' is manifest in many libertine English poems of the late sixteenth and early seventeenth centuries, which portray the paradise of free love where men and women indulge in innocent sensuality without fear or inhibition. The emphasis in such works is on voluptuous enchantment, the glorification of natural appetite, the innocence of sexuality, the denunciation of female chastity, and the rejection of conventional morality. This approach is based on the assumption that, in the happy Golden Age, the natural flow of passion is not hindered by the tyrant 'honour' bred of custom and opinion.

It might be illuminating at the outset to review briefly some relevant cross-currents of thought in the classical tradition. The Stoics focus on the universal law of nature as the basis of the moral code, representing the highest reason innate in human nature. In the words of Cicero, "True law is right reason in agreement with nature; it is of universal application, unchanging and everlasting." This is "valid for all nations and all times, and there will be one master and ruler, that is, God, over us all, for he is the author of this law."1 The concept has been adopted throughout the ages by Christian thinkers such as the early Fathers, Augustine, Aquinas, and Richard Hooker. By contrast with this ethical idealism, there is the doctrine of pleasure advocated by the Epicureans, who contend that voluptas is the natural and supreme value in life. Similarly, the Sceptics deny the moral sense on the grounds that there "is no natural justice or law, but men as well as all other living creatu res are governed naturally by utility," which "differs in different places."2 Since in their view no universal principles underlie the law of nature, the Sceptics maintain that the social code derives its force from mere custom and opinion, without any absolute validity or justification.

In the thought of the late Renaissance, Montaigne is perhaps the most influential sceptic, who distrusts all conventions and traditions, propagating a philosophy of excessive individualism and naturalism. In his last essays, the older Montaigne conveys a spirit of 'epicurean optimism' 
reminiscent of his early days as a young hedonist whose dominant feeling is frank desire. He writes: "I have ... taken for my regard this ancient precept, very rawly and simply: That 'We cannot erre in following Nature': and that the soveraigne document is, for a man to conforme himselfe to her. I have not ... by the power and vertue of reason, corrected my natural complexions, nor by Art hindered mine inclination" (III, 316). ${ }^{3}$ This often-cited statement suggests his freedom from Stoicism and Platonism, from rational idealism, from belief in any universal moral truth ascertainable by reason. In his essay, "Of Experience," Montaigne asserts that "Nature is a gentle guide ... which hath like a kinde mother observed this, that such actions as shee for our necessities enjoyned unto us, should also be voluptuous unto us" (III, 382). It is clear that he refers here to the needs of his own individuality, which transcend all philosophical speculation in ethics.

The foundation of Montaigne's primitivism lies in his concept of nature, expounded through various concrete situations instead of formal definitions. In his code of thought, nature is not just a superhuman force but a way of performing human actions, a guide to moral behaviour, a recipe for living. With the impact of America on his sensibility, Montaigne reveals his preference for the simplicity of natural men uncorrupted by artifice. His idealization of primitivism is most monumentally characterized by his essay, "Of the Caniballes," where he compares nations of the new world with the ideal republics of Plato and Lycurgus. In his emphasis on these nations' primitive perfection, Montaigne negates every basic institution of European society, marked above all by denial and repression. There is in this apotheosis of primitive life a profoundly subversive principle, capable of undermining traditionally established values and prejudices. Such speculations of the older Montaigne lead him to draw a clear distinction between nature and custom, asserting that natural inclinations and sensual gratifications are good and innocent. Sense and instinct seek and find their own temperance without the interference of reason, he maintains. In consequence, Montaigne regards custom as a harmful restraint, which hinders the attainment of pure knowledge and pleasure.

His explorations of sexuality recur tangentially or parenthetically in a large nu mber of essays, but he concentrates almost exclusively on it in his essay, "Upon Some Verses of Virgil," where he dwells on the notion of the sex act as a vital principle in everything and the centre of the human condition. Most important is Montaigne's profound attack on conventional taboos, which cause disruptive feelings of sin and guilt in the vital relationship between men and women: "Why was the acte of generation made so naturall, so necessary and so just, seeing we feare to speake of it without shame, and exclude it from our serious and regular discourses? ... It is an action we have put in the precincts of silence, whence we draw it were an offence: not to accuse or judge it" (III, 70). Montaigne suggests in this 
context that man is a miserable animal, unable to enjoy any pleasure without trying to create obstacles for himself above those which nature already offers, preferring local conventions to universal laws. In the last analysis, he holds, albeit cautiously, that enjoyment is the only test. In his arguments there is a clear denunciation of any repression of natural inclinations, which must be released for the perfect self-realization. The essay on "Virgil" is almost a hymn to pleasure, stressing again and again the Horatian carpe diem, the active, conscious, and intelligent determination to seize and magnify moments of pure enjoyment. The French thinker has imposed his own stamp on this hedonism, which is fundamentally a development of the Epicureanism of antiquity. Rejecting all rules and codes, he thinks little of timid and routine virtue, of such conventional values as honour and chastity. His basic argument is that morality must not be reduced to any merely routine system, that man must have the freedom to face situations untrammelled by habit, custom, precedent, or law.

Apparently, Montaigne's Essays had a marked impact on contemporary esprit libres in France, such as the tavern and vagabond poets, who questioned religious beliefs and conventional morals with cynical sophistication. For example, his temper and ideas are clearly reflected in the Satyre première of Théophile de Viau: "Japprouve qu'un chacun suive en tout la nature;/Son Empire est plaisant, et sa loy n'est pas dure"; "Je pense que chacun auroit assez d'esprit,/Suyvant le libre train que Nature prescrit." ${ }^{4}$ It has been rightly observed that "Nature is the mirror of [this] poet's soul: free, sensuous, and impulsive." 5 There is strong emphasis on the physical. appetitive side of human life in Théophile's raunchy verses, which often dwell on themes of blasphemy and anti-clericalism. Besides his playful ridicule of the sacred, he conveys a simple delight in sexual love and springtime in a pagan atmosphere, untouched by Christian associations of sin and chastity. The same kind of sensuality is typical of Théophile's close friend, Saint-Amant, with his picturesque expressions of indulgence. debauchery, and exuberance.

This leads us to consideration of sexual freedom in the Golden Age often portrayed by Renaissance painters, who laboured over the mythology used by the Greeks to express perfect human love. Their approach can be exemplified by Agostino Carracci's four paintings, now in the Kunsthistorisches Museum at Vienna. ${ }^{6}$ The pictures, usually called "The Golden Age" or "The Four Loves," represent the lost paradise of uninhibited sensuality and mutual fulfillment. Likewise, many poets depicted the happy paradise, where men and women concerned themselves with their own love and innocence, and not with honour, that tyrant created by custom and opinion, that enemy of nature. In this garden of fortunate innocents, with its feast of the senses, law and appetite are the same. 
The famous chorus which ends Act I of Tasso's Aminta (1573) provides a fascinating description of the Golden Age: "among streams and flowers the children of love... shepherds and nymphs sat down, mixing caresses and whispers with their words, and with the whispers kisses closely clinging; the naked virgin then discovered her fresh roses which now she hides in her veil, and the sharp, new apples of her breast, and often, in the spring or in the lake, the lover was seen playing with his beloved." But there was a serpent in this natural Eden of sexual gratifications:

You it was first, Honor, who veiled the source of delight, denying water to the thirst of love; you taught lovely eyes to hide within themselves and hold their beauties secret; ... you made sweet lascivious deeds into deeds of contrariety and reserve; you imposed a check on words, and art on movement ...?

A poetic translation of this chorus by Tasso can be found in Samuel Daniel's "A Pastorall," which describes honour as the "Idoll of deceit," "the tyran of the minde."

Such aspects of naturalism are also paralleled in the libertine poems of Thomas Nashe, John Donne, Thomas Randolph, Richard Lovelace, and Thomas Carew, among many others. In Thomas Blount's Glossographia (1656), libertinism is defined as "the state of him that of Bond is made free; Licentiousness, Epicurism. In Divinity it is thus defined. Libertinism is nothing else but a false liberty of belief and manners, which will have no other dependence but on particular fancy and passion." The term is also related to a popular misconception in the later Renaissance of Hobbes' 'natural man,' the typical 'libertine': cynical, dissolute, treacherous, lustful, recognizing no moral restraint in his relations with women, and disregarding any ethical criterion but success.

These traits are unmistakable in many of John Donne's poems, where he assumes the role of the sexual libertine, the young man of the world who glorifies inconstancy as the only constant element in love. His Elegy "Change" delineates the idea that the infinite variety of love mirrors the state of constant flux in nature. With profound interest in purely physical relations as the natural condition of liberty, Donne treats women as mere objects of lust to be tried, enjoyed, and discarded lightheartedly. The credo of naturalism is set forth clearly in "Variety," which Helen Gardner includes among the Dubia in her edition of Donne's poems. ${ }^{9}$ The speaker looks back with nostalgia at the Golden Age: "How happy were our Syres in ancient time,/Who held plurality of loves no crime!" This is followed by sophisticated arguments against social restraints, which have no justification in terms of the natural order: 
But since this title honour hath been us'd,

Our weake credulity hath been abus'd;

The golden laws of nature are repeald,

Which our first Fathers in such reverence held;

Our liberty's revers'd, our Charter's gone,

And we made servants to opinion,

A monster in no certain shape attir'd,

And whose originall is much desir'd,

Formlesse at first, but growing on it fashions,

And doth prescribe manners and laws to nations.

The central argument in the passage is based on the contrast between "golden laws of nature" and the "monster" of "opinion," which "doth prescribe manners and laws to nations."

The denunciation of legalistic ethics that inhibit lovers is echoed in "The Relique," where the poet laments: "Our hands ne'r toucht the seales,/ Which nature, injur'd by late law, sets free." Moral qualities are portrayed as allegorical figures and reduced to figments of the imagination in "The Dampe": "First kill th'enormous Gyant, your Disdaine,/And let th'enchantresse Honor, next be slaine ..." Similarly, in "A Valediction: Of the Booke," honour and conscience are dismissed as chimeras. The striking process of seduction in "The Flea" is based preeminently on equating the lady's honour with the drop of blood sucked by the flea and related to the "losse of maidenhead." Sexual intimacy is organically associated with the "blood of innocence," in which she has "purpled" her "naile" by killing the flea. Whereas in "The Dreame," rebellion against conventional morality is blended with erotic realism and an opaque hint of libertine atheism. The lady, through some kind of telepathy, comes to her lover's room for an act of sex when she is most needed, excess of joy waking him from an erotic dream of her. Her ability to read his thoughts implies she has a knowledge beyond that of angels and peculiar to God; unless indeed she is superior to God: "I doe confesse, it could not chuse but bee/Prophane, to thinke thee any thing but thee." But she has to leave for fear of scandal, hence the admonition that pure love should not have a "mixture" of "Feare, Shame, Honor." Such aspects of Donne's libertinism are in perfect harmony with the statements by Montaigne or Tasso cited earlier. Although it is quite conceivable that he was familiar with them, that does not imply any direct influence on him, since these elements of naturalism are so diffused in the classical and Renaissance traditions that they cannot be traced to any specific source.

The Ovidian tradition, however, most likely inspired Donne's Elegy "To his Mistris Going to Bed," which has been aptly described as "a piece of frank naturalism redeemed from coarseness by passion." 10 In general 
terms, the poem calls to mind the scene in Amores.I.v, where Corinna comes to visit the poet in his room; he then tears away her clothes and, having admired her naked beauty, takes her to his bed. In his book on Donne, John Carey describes the Elegy as "a bawdy poem": "The despotic lover here, ordering his submissive girl-victim to strip, and drawing attention to his massive erection .... is of course a perennial dweller in the shadowland of pornography." He adds that Donne "contrives to sound, provokingly, high-minded and dissolute at the same time. Similarly he exhibits his command of religious language while flaunting his disregard of religion." 11 Indeed the religious trope of "imputed grace" in the poem, which seems to equate the lady with Christ, verges on blasphemy. The speaker considers himself to be one of the elect since the lady has chosen him for the bliss of sexual intimacy. In a scathing review of Carey's book. William Empson accuses him of heing prejudiced and sanctimonious, contending that he misread the Elegy because "he was using a bad text, that of Dame Helen Gardner," which "no longer serves any purpose, and had better be abandoned." 12 She makes the climax of the poem say: "Here is no pennance, much lesse innocence." This was probably the original form of the line ${ }^{13}$ but it is totally inconsistent with the rest of the piece. Having celebrated the sheer ecstasy of sexual intercourse and argued that the experience is divine, the speaker appears to tell the lady at the very moment of penetration that she will go to hell for it. Such an approach is nothing short of sadistic pornography.

The crux of the matter in terms of naturalism lies in Grierson's version of the line which reads: "There is no pennance due to innocence." Many of Donne's tropes in the poem focus on the argument that sexual pleasure is a part of heaven, a part of the paradisal experience. In this context, his reference to "Mahomets Paradise" is apt and illuminating, evoking as it does associations of the sensuous description of paradise in the Koran, which abounds with houris intended to stimulate desire, hence the logical conclusion that there is no penance for sexual intimacy because the act is pure and innocent. Donne implicitly alludes to the Golden Age, where free love negates all religious restrictions and moral scruples. It should be noted. however, that in his appeal to nature as a guide and norm, as a substitute for the authority of society and its ethical code, he is not unique; the ideas expressed with "masculine persuasive force" in his libertine poetry were becoming fashionable in his day.

Note, for example, the situation in Thomas Randolph's "Upon Love fondly refus $\mathrm{d}$ for Conscience sake," which begins: "Nature, Creations law, is judg d by sense $/$ Not by the Tyrant conscience." Taking nature as his own unique lawgiver, the poet accentuates the innocence of sense in order to exalt sensuality and condemn the tyrant 'honour,' meaning merely female chastity. In the Golden Age, he says, it is the lovers' decree to follow the 
prompting of "youth and pleasure." They are ruled by "higher powers," which make passion lawful and desirable.

For we must question else heavens great decree,

And taxe it with a Treachery;

If things made sweet to tempt our appetite

Should with a guilt stain the delight. ${ }^{14}$

In the same vein, Richard Lovelace writes in "Love made in the first Age":

Because no fault, there was no tear:

No grone did grate the granting Ear;

No false foul breath their Del'cat smell:

No Serpent kiss poyson'd the Tast.

Each touch was naturally Chast.

And their mere Sense a Miracle. ${ }^{15}$

As in Tasso's chorus, this paradise of sexual indulgence reveals the lovers "Naked as their own innocence," without any sense of shame or guilt.

The trend of naturalism in some libertine English poems was probably enhanced and accentuated by the vogue of Pietro Aretino's works of pornography, Ragionamenti and I Sonetti Lussuriosi, which reflect a combination of obscene language, robust joie de vivre, intellectual vigour, and anti-clericalism. In the first book, two harlots dwell on the techniques and practices of sex through dialogues about the lives of nuns, married women, and courtesans. The second includes sixteen sonnets dealing with modes of intercourse, accompanied by pictures of sexual positions, usually called I Modi, designed by Giulio Romano and engraved by Marcantonio Raimondi. In a letter dealing with censorship. Aretino defends the Sonetti, using arguments familiar in Montaigne:

I am all out of patience with their scurvy strictures and their dirty-minded laws which forbid the eyes to see the very things which delight them most. What wrong is there in beholding a man possess a woman? It would seem to me that the thing which is given to us by nature to preserve the race. should be worn around the neck as a pendant, or pinned onto the cap like a broach, for it is the spring which feeds all the rivers of the people, and the ambrosia in which the world delights in its happiest days ... It has begotten the loveliest of children, the most beautiful of women and the holiest of saints. ${ }^{16}$

Aretino often rails, in a spirit of scepticism and cynicism, at the tyranny of man-made laws and ancient traditions in favour of the primitive laws of nature, thus reflecting the perspectives of the libertine tradition.

There are numerous reference to his "pictures" and "dialogues" in works by Spenser, Richard Harvey, Robert Greene, Thomas Lodge, Thomas 
Nashe, Gabriel Harvey, John Marston, Donne, Ben Jonson, Robert Burton, and even Milton. ${ }^{17}$ As might be expected, the allusions to his "filth" a re often adopted in invective to smear the reputation of literary enemies, or in moral and political satire to libel the Roman Catholics, condemn the Italians, expose the licentiousness of court life, denounce the sinfulness of the flesh, or reveal the corruption of human nature. The main principle underlying their use in satire is depravity and guilt by association.

Yet Aretino's radical approach to sexual freedom provided the primary model for some libertine English works such as The Choice of Valentines, ${ }^{18}$ described by David Frantz as "one of the few unadulterated pornographic works of the English Renaissance." 19 There can be little doubt that the piece was written by Nashe, making him vulnerable to charges of bawdry from Gabriel Harvey and John Davies of Hereford. However, this explicitly obscene poem, which may have some connection with Donne's outrageous Elegy "Loves Progress," has little value as a literary work. The spirit of Aretino can also be clearly perceived in Thomas Carew's "A Rapture," ${ }^{20}$ perhaps the most sustained piece of naturalism, eroticism, and magnificent licentiousness in the later English Renaissance. Certain images in the poem are reminiscent of Aretino's 'pictures,' as when Carew describes the sexual activity of the lips (11. 67-72), which calls to mind allusions to oral sex in both the Sonetti and the Ragionamenti. Although the parallel could be more than mere coincidence, it is quite difficult to prove any specific debts in this matter. There is, however, a particular reference to the Italian pornographer in association with Lucrece, the paragon of matronly virtue, and Lais, the famous courtesan of Corinth:

The Roman Lucrece there, reades the divine

Lectures of Loves great master, Aretine,

And knowes as well as Lais, how to move

Her plyant body in the act of love.

The poet aggressively denounces chastity which leads to denial and negation. In his golden paradise of sensual ecstasy, "Husband, wife, lust, modest, chaste, or shame,/Are vaine and empty words..." "All things are lawfull there, that may delight/Nature, or unrestrained Appetite." In his celebration of sex, Carew launches a relentless attack on conventional ideas of marriage, fidelity, and modesty in defence of uninhibited indulgence in the delights of physical union. He provocatively states that the "Gyant, Honour, that keepes cowards out,/Is but a Masquer ...," a tacit denunciation of moral hypocrisy which denies a passage to "tame fools."

The influence of "A Rapture" is evident in such lyrics as John Cleveland's "To Chloris: A Rapture," Thomas Randolph's "A Pastorall Courtship," and William Cartwright's "Song of Dalliance." Carew's poem also has close affinities with a passage in The Tragedy of Nero, Newly Written, which is 
full of echoes from the courtly poets. This verse-drama, published anonymously in 1624 and reprinted in 1633, conveys a vivid picture of free love. The author depicts death as the pathway to a paradise full of "all curious pleasures" of the senses. Such a pastoral and idyllic world represents the Golden Age of primitive innocence, naturalness, and beauty, untouched by the artificial restrictions of human society. In words which bear a striking resemblance to linesabout Lucrece in "A Rapture," the writer portrays her as a woman of insatiable sexual desire:

Faire Lucrece lies, by lusty Tarquins side, And wooes him now againe to ravish her. Nor us (though Romane) Lais will refuse, To Corinth any man may goe ...21

Thus both Carew and the author of Nero play a variation on the ancient legend of Lucrece, raising the possibility of a different conduct on her part, founded on indulgence in pure sensuality, instead of clinging to the myth of honour.

As we have seen, this sceptical approach to conventional ethics finds eloquent expression in the naturalism and primitivism of Montaigne, which can be traced back to classical sources. The English libertines advocate an alternative code of behaviour, where all barriers set up by decorum, rank, religion, and morality should be nullified. In a sense, they represent the tensions between ethical values and psychological needs, between the individual and society. Reflecting the anti-sublime treatment of lust, these writers advance their own "truth" which is to a large extent a donnée. In opposition to the traditional idealism behind the pastoral and the love lyric, they present a sexual experience which is particularly destructive to the romantic vision of honour and purity. Their urbanely cynical perspective transcends all restrictions imposed by social and religious norms.

\section{University of Calgary}

Notes

1 Cicero, De re publica, trans. Clinton Walker Keyes (London: Heinmann, 1928; reprint ed., Cambridge, MA.: Harvard University Press, 1961), III, 22, 211.

2 Ibid., III, 12, 201.

3 All citations from Montaigne refer to Montaigne's Essays, trans. John Florio, with an introduction by L. C. Harmer (London: J. M. Dent, 1965). Volume and page numbers are inserted in parentheses.

4 Théophile de Viau, CEuvres Complètes, ed. Guido Saba (Paris: A. G. Nizet; Rome: Edizioni dell' Ateneo, 1984), I, 399, 405.

5 Claire Lynn Gaudiani, The Cabaret Poetryof Théophile de Viau: Texts and Traditions (Paris: JeanMichel Place, 1981), p. 28.

6 Cited by Wayland Young, Eros Denied: Sex in Western Society (New York: Grove Press, 1964), p. 307. Two of Agostino Carracci's paintings are reproduced at Plates 27 and 28 of this book. 
7 Ibid.p. p. 302.

8 Samuel Daniel, Delia in The Whole Workes (London. 1623). p. 178 of second pagination.

9 All citations from Donne refer to The Elegies and The Songs and Sonnets of Jolin Donne, ed. Helen Gardner (Oxford: Clarendon Press, 1970). Gardner (p. xliv) doubts Donne's authorship of "Variety" because in this poem, "as in some of the other Elegies discussed, we have themes treated that Donne treated, but. again, they are not treated in his way. The poem is gay and impudent where Donne is insolent and insulting. gallant where he is brutal." On the other hand, it is included as "Elegie XVII" in Herbert Grierson's edition. The Poems of John Donne (Oxford: Oxford University Press. 1912).

10 George Saintsbury, "John Donne," in John Donne: A Collection of Critical Essays, ed. Helen Gardner (Englewood Cliffs. NJ.: Prentice-Hall. 1965). p. 18.

11 John Carey, John Donne: Life, Mind and An (New York: Oxford University Press, 1981), pp. 105. 106.

12 William Empson, "There Is No Penance Due To Innocence," The New'York Review', 3 December 1981.p. 43.

13 See Grierson. Poems of John Donne. 11. 90: Gardner. Elegies, Songs and Sonnets of Donne. p. 133.

14 English Seventeenth-Centur. Verse. Vol. 11. ed. Richard S. Sylvester (New York: W. W. Norton. 1969). p. 419.

15 The Poems of Richard Lovelace, ed. C. H. Wilkinson (Oxford: Clarendon Press, 1953). p. 147.

16 The Letters of Pietro Aretino, trans. Thomas Caldecot Chubb (n.p.: Archon Books. The Shoe String Press for Yale University Library. 1967). p. 124. For the Italian text, see Pietro Aretino: Il Primo Libro delle Lettere, ed. Fausto Nicolini (Bari: Latezra \& Figli. 1913). p. 397.

17 See my "Aretino's Pornography in the Later English Renaissance." English Miscellany, XXV (1975-1976). 97-119.

18 See The Works of Thomas Nashe. ed. R. B. McKerrow and rev. F. P. Wilson (Oxford: Basil Blackwell, 1958). 111. 403-416.

19 David Frantz." "Leud Priapians” and Renaissance Pornography." S. E. L. 1500-1900, XII (Winter 1972). 170.

20 Citations from "A Rapture" refer to The Poems of Thomas Carew', ed. Rhodes Dunlap (Oxford: Clarendon Press. 1949). pp. 49-53.

21 The Tragedy of Nero. New!y. Written (London. 1624), fol. G4v . 